\title{
Using genomics to improve fruit quality
}

\author{
Claudio Meneses ${ }^{1}$ and Ariel Orellana ${ }^{1,2, *}$ \\ 1 Centro de Biotecnología Vegetal, Facultad de Ciencias Biológicas, Universidad Andrés Bello. \\ 2 FONDAP Center for Genome Regulation.
}

\begin{abstract}
New fruit varieties are needed to satisfy consumers, and the industry is facing new challenges in order to respond to these demands. The emergence of genomic tools is releasing information on polymorphisms that can be utilized to expedite breeding processes in species that are difficult to breed, given the long periods of time required to get new varieties. The present review describes the current stages of the ongoing efforts that are being taken to apply these technologies to obtain varieties with improved fruit quality in species of the family Rosaceae.
\end{abstract}

Key words: Polymorphisms, Marker Assited Selection, Genomic Tools.

The market is demanding fruit with better quality. In addition to aspects important for consumers such as flavor, aroma and consistency, among others, the globalized world has expanded the places where they are produced and sometimes fruit needs to be shipped long distances to reach its final markets. This poses a challenge, since fruit quality also has to respond to extended post-harvest storage without affecting fruit quality. Finally, the effects of climate change are perturbing the climatic conditions where fruits have been historically produced, therefore, the new varieties also need to be better adapted to grow in harsher conditions. Breeding is the main process utilized to obtain new varieties. However, new approaches are required to breed fruit varieties that respond to the emerging challenges. The identification of molecular determinants, along with the generation of selection markers for traits of interest, offer an opportunity to respond to these challenges. In recent years the genomes of some fruit species of the Rosaceae have been sequenced (Velasco et al., 2010; Shulaev et al., 2011; Verde et al., 2013; Zhang et al, 2012a; Wu, 2013), leading to a great expansion in the identification of selection markers that can be applied in breeding programs to expedite the development of varieties that respond to the emerging challenges. In the present review we focus on the new trends that are emerging in relationship to the use of genomic tools and the identification of selection markers in species of the Rosaceae.

\section{FRUIT BREEDING AND MARKER-ASSISTED SELECTION IN} ROSACEAE

The Rosaceae contains over 100 genera and 3,000 species. It is the third most economically important plant family in temperate regions (Dirlewanger et al., 2002), including species of economic importance such as apple (Malus $x$ domestica), peach (Prunus persica), strawberry (Fragaria ananassa), plum (Prunus salicina), almond (Prunus dulcis), pear (Pyrus communis), European plum (Prunus domestica) and sweet cherry (Prunus avium), among others. The total world production of edible rosaceous fruits reached about 145 million tons, with 998,000 hectares harvested in 2011 (FAO, 2013). For this reason, initiatives to generate new fruit varieties that can be adapted to the local agronomic conditions and satisfy the requirements of the consumer have been carried out in the last 50 years. In recent years breeding programs have been dealing with increasing challenges, including the development of improved varieties for traits that have complex genetic control (quantitative traits). These programs must deliver results in the shortest possible time and they also need to be adapted to local agricultural climatic conditions. For a long time the breeding programs focused their efforts on developing varieties with superior performance in terms of production (yield, average fruit size) and commercial features (full surface color), in order to satisfy the grower's requirements, without considering the needs of final consumers (fruit quality). At present, improving fruit quality is one of the main goals for growers and breeders in species of the Rosaceae, since the ultimate goal of the industry is to satisfy consumers. Phenotypic expression of most fruit quality traits is quantitative. They are based on complex biochemical processes that are often determined by the interaction of various genes involved in different metabolic pathways, such as soluble solids content, titratable acidity, flesh firmness and juiciness (Illa et al., 2010). The strategy used by most breeding programs is based on performing hundreds of controlled crosses to select from thousands of individuals a few exhibiting the target traits. This approach has been successful in producing most of the varieties that today are available in the market. However, it has a number of disadvantages, since this strategy is particularly time consuming and costly in fruit trees because of the length of time required to obtain fruit production (2-3 years for peach and 3-5 years for apple) and the resources to maintain the seedlings in the field during the evaluation and selection processes. In fact, at least 12-20 years are needed to obtain one new Rosaceae fruit tree variety. For this reason, the development of genomic tools to support the early selection of genotypes may be the key to improve the efficiency of breeding programs.

\section{USING GENOMIC TOOLS TO OBTAIN MARKERS FOR SELECTION}

The advances in DNA sequencing technologies speeded up the unraveling of genomes from different species; to date 
several genomes of the Rosaceae have been sequenced Table 1 including Malus x domestica (apple), Fragaria vesca (strawberry), Prunus persica (peach), Prunus mume and Pyrus bretschneider (Velasco et al., 2010; Shulaev et al., 2011; Verde et al., 2013; Zhang et al, 2012a; Wu, 2013). In addition, the sequences of Prunus amygdalus (almond) and Prunus avium (sweet cherry) have been recently made available to the research community (http: / / genomicsdata.wsu.edu/public_access/index.php). The availability of these genomes made easier to re-sequence the genome of other individuals from the same species and identify polymorphisms or structural variants present in their genomes, such as single nucleotide polymorphisms (SNPs), insertions/deletions (INDELs), copy number variants and translocations. Since SNPs are by far the most abundant polymorphisms present in all genomes, most of the efforts in searching for markers that may be useful in assisted breeding selection has been targeted to this class of polymorphisms.

SNPs are widely distributed in the genome; they can be located in inter- or intragenic regions. The first attempts to identify SNPs using sequencing technologies approaches began by investigating their presence in expressed genes using expressed sequence tags (ESTs). An interesting feature of SNPs located on ESTs is the possibility to establish a link between functional and structural genomics. However, there are some limitations when low coverage sequencing technologies are utilized, since SNPs discovery is dependent on the expression level, and it is difficult to obtain SNPs for low expression genes. Furthermore, some problems may also arise in discriminating paralogous genes. Despite these constraints, this approach proved to be successful for identifying SNPs in apple (Chagne et al., 2008), almond (Wu et al., 2008) and strawberry (Bombarely et al., 2010). The emergence of the so-called next generation sequencing technologies (NGS) not only improved genomic sequencing but also made it possible to perform transcriptome analyses at higher coverage (RNAseq analyses). This methodological upgrade expanded and improved the detection of polymorphisms in expressed genes. Thus, more than 2,000 SNPs were obtained by comparing the transcriptome of Bing and Rainier, two cherry cultivars (Koepke et al., 2012), and more than 9,000 SNPs were detected in the peach transcriptome (Wang et al., 2013).

Wide genome sequencing of different individuals expanded the identification of polymorphisms. This analysis has the advantage that in theory we can obtain a broad heterogeneity within a given species; however, this is a challenging process since many individuals exhibiting the whole diversity of that species need to be represented. Moreover, using current technologies it is not possible to re-sequence the whole genome in an affordable manner. However, for breeding purposes, the use of NGS technologies to obtain genomic information from those individuals that could be used as parents is enough to provide information on polymorphisms that can be useful markers. For example, in apple the genomic sequencing of 27 cultivars led to the identification of more than 2 million SNPs (Chagne et al., 2012a); in pears, the sequencing of three European cultivars identified more than 1 thousand SNPs (Montanari et al., 2013); in peach the sequencing of two varieties obtained more than 6,000 SNPs (Ahmad et al., 2011) while a more recent effort, sequencing 56 breeding accessions, identified more than 1 million SNPs (Verde et al., 2012).
All this effort searching for SNPs has been transformed in a collection of polymorphic SNPs from different species, deposited in chip arrays that have been useful to construct high density genetic maps of populations. More important, these chip arrays are a relevant step towards the identification of genome regions that are key in defining complex agricultural traits (Verde et al., 2012; Chagne et al., 2012a; Montanari et al., 2013).

\section{HOW TO TRANSFORM A POLYMORPHISM INTO A SELECTION MARKER?}

Once the molecular markers are available, it is necessary to establish a link between the genetic markers and the fruit quality traits. To do this, there are several methodological alternatives which have been used with relative success and there are two widely accepted: quantitative trait loci (QTL) analysis and association mapping. Although these strategies are pre-NGS era, at present thousands of polymorphisms are available in several Rosaceae fruit tree species and these can be expanded using NGS platforms. All this information along with the possibility of genotyping hundreds of individuals, including segregants from bi-parental mapping populations or varieties, improves the probability to find markers linked to traits; due to a higher resolution of the genetic maps, the genome coverage is better and the genetic variability is abundant due to the number of individuals considered in the analysis. Thus genetic linkage maps, QTL analysis and linkage disequilibrium maps appear to provide tools that will allow the dissection of complex genetic traits and marker-assisted selection of economic importance traits.

Genetic Linkage Maps and QTL Analysis: A linkage map may be thought as a 'road map' of the chromosomes derived from two different parents (Paterson, 1996) that indicates the position and relative genetic distances considering the recombination rate between markers in chromosomes. The most important use for linkage maps is to indentify chromosome regions containing genes and QTLs associated with traits of interest. Genetic map construction has three steps: i) generation of the mapping population, II) polymorphism identification and iii) linkage analysis of markers (Collard et al., 2005). QTLs are chromosome regions containing one or more genetic factors that are responsible for a fraction of the phenotypic variation of a quantitative trait (Tanksley, 1993). QTL analysis is based on the principle of detecting an association between phenotypes and the genotypes of markers distributed in the genome. Markers are used to divide the mapping population into different genotypic groups based on the presence or absence of a particular marker locus and to determine whether significant differences exist between groups in relationship to the trait being measured (Tanksley, 1993; Young, 1996).

Until recently, most of the markers used in genetic analyses were simple sequence repeats (SSRs); however, their availability is not high, therefore the resolution of the genetic maps was low. In spite of this, QTLs for flowering and ripening time, fruit quality, tree architecture and resistance to pathogens have been reported (Dirlewanger et al., 1996; Abbott et al., 1998; Dirlewanger et al., 1999; Etienne et al., 2002; Quilot et al. 2004; Dirlewanger et al., 2006; Lambert et al., 2007; Ogundiwin et al., 2008; Dirlewanger et al., 2009). In addition, QTLs for fruit weight, soluble solid content and acidity have 
been reported (Dirlewanger et al., 1999; Etienne et al., 2002; Verde et al., 2002; Dirlewanger et al., 2009), as well as chilling injury (Cantín et al., 2010). Furthermore, QTL analyses were carried out for fruit size in apple (Stoeckli et al., 2008; Kenis et al., 2008; Davoghalaere et al., 2012; Potts et al., 2013), acidity (Xu et al., 2012; Zhang et al., 2012b; Kenis et al., 2008; Potts et al., 2013), soluble solid content (Kenis et al., 2008; Potts et al., 2013), harvest date (Kenis et al. 2008) flowering date (Celton et al., 2012), fruit maturity (Morimoto et al. 2013), fruit number (Stoeckli et al., 2009), volatile organic compounds (Zini et al., 2005; Dunemann et al., 2009; Dunemann et al., 2012; Khan et al., 2012; Chagne et al., 2012b; Vogt et al., 2013; Costa et al., 2013), texture (King et al., 2000; King et al., 2001; Kenis et al., 2008; Costa et al., 2008; Costa et al., 2010; Longhi et al., 2012; Longhi et al., 2013), ethylene production (Costa et al., 2014), Vitamin C content (Davey et al., 2006; Mellidou et al., 2012;) and flesh browning (Kenis et al., 2008; Di Guardo et al., 2013). Also, as the cost of map construction was higher, the efforts were concentrated in a few mapping populations and often they were considered as reference progenies, but these populations only segregated for a few traits. For example, the genetic reference map of Prunus (Dirlewanger et al., 2004) was built using a mapping population obtained from the interspecific cross between almond and peach. At first this population was very appropriate, because it showed a high level of polymorphism and most markers probed were polymorphic. However, despite the marker saturation, this population does not have segregating phenotypes for fruit quality.

At present, SNP discovery using NGS platforms is faster and cheaper per data point. In addition, high performance SNP genotyping systems are available. This allows the generation of saturated genetic maps and QTL detection using these technologies. In peach, QTL analysis for fruit quality traits has been undertaken by Eduardo et al. (2011), in which maps based on SSRs were initially constructed on the mapping population Bolero x Oro A. Subsequently, they saturated the Bolero and Oro A maps using SNPs contained in the Illumina 9,000 SNP array v1 for peach (Verde et al., 2013). Thus a total of 1,453 and 229 SNPs in Bolero and Oro A were mapped, respectively (Eduardo et al., 2012). Based on this approach co-localization between candidate genes and major QTLs were detected: two putative terpene synthases and one lipoxygenase (Lox) might be involved in the biosynthesis of linalool, p-menth-1-en-9-al and nonanal, respectively. The contribution of the SNP array helped to generate a saturated map and the resolution and coverage improved considerably. Similarly, QTLs for texture were detected by Longhi et al. (2012) in apples. Two maps were saturated using SNPs that were identified during an early assembly draft ( $4 \mathrm{X}$ sequencing depth) of the Golden Delicious genome sequencing effort (Micheletti et. al., 2011). From this study, candidate genes for texture and ripening have been identified (Longi et al., 2012; Costa et al., 2014). In cherries, NGS sequencing was used to discover SNPs, providing markers for genetic and genomic studies. High-density genetic maps of four parental lines and two segregating populations were built using the RosBREED cherry 6K SNP array v1 (Klagges et al., 2013). This is the first step to identify genes that may be involved in fruit quality on this species.

Association mapping. There is increasing interest in using association mapping or linkage disequilibrium mapping (LD) to identify genes responsible for complex traits. This approach is a new alternative to linkage analysis (bi-parental crosses) and it provides three advantages: increased map resolution, reduced research time since it is not necessary to develop segregating populations for traits of interest, and greater allele numbers (Zhu et al., 2008). Besides, linkage analysis is limited by the low number of recombination events that occur in a mapping bi-parental population, while association mapping uses the historical recombination and natural variation of a set of accessions that could represent the total phenotypic variation for many traits. This approach is based on using genotype information from genetic markers distributed throughout the genome to account for genetic relationships by association tests. The genetic relationship determined by linkage disequilibrium measures the degree of non-random association between alleles at different loci, which also could be related to a specific trait. Association mapping includes i) germplasm selection, providing the maximum genetic variability for a given trait; ii) germplasm genotyping; iii) determining the phenotypes of the traits of interest; iv) genotyping the germplasm using a large number of markers and v) association analyses. In model plant species such as Arabidopsis (Aranzana et al., 2005; Tracy et al., 2006; Belo et al., 2008;) and economically important crops such as maize (Andersen et al., 2005; Salvi, 2007), sorghum (Casa et al., 2008) and barley (Kraakman et al., 2006) association mapping studies have been reported. In Rosaceae, Longhi et al. (2013) determined the LD among markers identified within the apple cultivar collection, and haplotypes for these markers were associated with flesh textures. A genome-wide association study (GWAS) in 1,200 apple (Malus $\times$ domestica Borkh.) seedlings, genotyped using the $8 \mathrm{~K}$ SNP array, was carried out by Kumar et al. (2013). They reported the first systematic evaluation of the relative contributions of different genomic regions to various traits related to eating quality and susceptibility to some physiological disorders. Chromosome regions were identified with significant effects on several traits. Other efforts in association mapping have been carried

\section{TABLE 1}

Genomes sequenced of some members of the Rosaceae family including SNPs detected in these species

\begin{tabular}{lcccc}
\hline \multicolumn{1}{c}{ Species } & $\begin{array}{c}\text { Genome size } \\
\text { determined (Mbp) }\end{array}$ & $\begin{array}{c}\text { Genome size } \\
\text { estimated (Mbp) }\end{array}$ & SNPs & Reference \\
\hline Pyrus bretschneideri & 512 & 527 & 3402159 & Wu et al., 2013 \\
Prunus persica & 224.6 & 265 & 953357 & IPGI, 2013 \\
Malus x domestica & 598.3 & 742.3 & 2113120 & Velasco et al., 2010; Chagne et al., 2012 \\
Prunus mume & 237 & 280 & 200627 & Zhang et al., 2012; Sun et al., 2013 \\
\hline
\end{tabular}


out in pear (Inoue, et al., 2007; Iwata, et al., 2013) and peach (Aranzana et al., 2010), but using hundreds of SSRs. The availability of SNP chips should improve their discoveries.

\section{FINAL REMARKS}

Genomic studies are identifying an increasing number of SNPs. This information, combined with the work on segregating populations, or by using association mapping, should lead to an increasing number of markers that can be used in the early selection of varieties in breeding programs. However, in order to obtain markers that are accurate in their prediction, a great deal of effort needs to be made in phenotyping those features that are important for the consumers as well as the industry. In addition, these approaches should also lead us to the identification of genes involved in determining the molecular components involved in defining complex traits. Thus another important product of these studies will be a better understanding of the biology behind processes that reach our senses.

\section{ACKNOWLEDGEMENTS}

This work has been supported by FONDECYT \# 11121396; FONDAP-CRG 15090007; ICM P10-062-F; PB 16.

\section{LITERATURE CITED}

ABBOTT AG, RAJAPAKSE B, SOSINSKI B, LU ZX, SOSSEY-ALAOUI $K$, GANNAVARAPU M, REIGHARD GL, BALLARD RE, BAIRD WV, SCORZA R, CALLAHAN A (1998) Construction of saturated linkage maps of peach crosses segregating for characters controlling fruit quality tree architecture and pest resistance. Acta Hort 465:41-49.

AHMAD R, PARFITT DE, FASS J, OGUNDIWIN E, DHINGRA A, GRADZIEL TM, LIN D, JOSHI NA, MARTINEZ-GARCIA PJ, CRISOSTO CH (2011) Whole genome sequencing of peach (Prunus persica L) for SNP identification and selection. BMC Genomics 12.

ANDERSEN JR, SCHRAG T, MELCHINGER AE, ZEIN I, LÜBBERSTEDT T (2005) Validation of Dwarf8 polymorphisms associated with flowering time in elite European inbred lines of maize (Zea mays L). Theor Appl Genet 111:206-217.

ARANZANA MJ, ABBASSI E, HOWAD W, ARÚS P (2010) Genetic variation population structure and linkage disequilibrium in peach commercial varieties. BMC Genetics vol 11:69.

ARANZANA MJ, KIM S, ZHAO K, BAKKER E, HORTON M, JAKOB K, LISTER C, MOLITOR J, SHINDO C, TANG C, TOOMAJIAN C, TRAW B, ZHENG H, BERGELSON J, DEAN C, MARJORAM P, NORDBORG M (2005) Genome-wide association mapping in Arabidopsis identifies previously known flowering time and pathogen resistance genes. PLoS Genet 1:e60.

BELO A, ZHENG P, LUCK S, SHEN B, MEYER DJ, LI B , TINGEY S, RAFALSKI A (2008) Whole genome scan detects an allelic variant of fad2 associated with increased oleic acid levels in maize. Mol Genet Genomics 279:1-10.

BOMBARELY A, MERCHANTE C, CSUKASI F, CRUZ-RUS E, CABALLERO JL, MEDINA-ESCOBAR N, BLANCO-PORTALES R, BOTELLA MA, MUÑOZ-BLANCO J, SÁNCHEZ-SEVILLA JF, ALPUESTA V (2010) Generation and analysis of ESTs from strawberry (Fragaria $x$ ananasa) fruits and evaluation of their utility in genetic and molecular studies. BMC Genomics 11:503.

CASA AM, PRESSOIRA G, BROWN PJ, MITCHELL SE, ROONEY WL, TUINSTRAC MR, FRANKS CD, KRESOVICHA S (2008) Community resources and strategies for association mapping in sorghum. Crop Sci 48:30-40.

CANTÍN CM, CRISOSTO CG, OGUNDIWIN EA, GRADZIEL T, TORRENTS J, MORENO MA, GOGORCENA Y (2010) Chilling injury susceptibility in an intra-specific peach [Prunus persica (L) Batsch] progeny. Postharvest Biology and Technology 58:79-87.

CELTON JM, MARTÍNEZ S, JAMMES MJ, BECHTI A, SALVI S, LEGAVE JM, COSTES E (2012) Deciphering the genetic determinism of bud phenology in apple progenies: a new insight into chilling and heat requirement effects on flowering dates and positional candidate genes. New Phytologist 192:378-392.

CHAGNÉ D, CROWHURST RN, TROGGIO M, DAVEY MW, GILMORE B, LAWLEY C, VANDERZANDE S, HELLENS RP, KUMAR S, CESTARO A, VELASCO R, MAIN D, REES JD, IEZZONI A, MOCKLER T, WILHELM L, VAN DE WEG E, GARDINER SE, BASSIL N, PEACE C (2012a) Genome-wide SNP detection validation and development of an 8K SNP array for apple. PLoS ONE 7(2): e31745.

CHAGNÉ D, KRIEGER C, RASSAM M, SULLIVAN M, FRASER J, ANDRÉ C, PINDO M, TROGGIO M, GARDINER SE, HENRY RA, ALLAN AC, MCGHIE TK, LAING WA (2012b) QTL and candidate gene mapping for polyphenolic composition in apple fruit. BMC Plant Biology 12:12.

CHAGNÉ D, GASIC K, CROWHURST RN, HAN Y, BASSETT HC, BOWATTE DR, LAWRENCE TJ, RIKKERINK EHA, GARDINER SE, KORBAN SS (2008) Development of a set of SNP markers present in expressed genes of the apple. Genomics 92:353-358.

COLLARD B, JAHUFER M, BROUWER J, PANG E (2005) An introduction to markers Quantitative Trait Loci (QTL) mapping and marker-assisted selection for crop improvement: The Basic concepts. Euphytica 142:169-196.

COSTA F, CAPPELLIN L, FARNETI B, TADIELLO A, ROMANO A, SOUKOULIS C, SANSAVINI S, VELASCO R, BIASIOLI F (2014) Advances in QTL mapping for ethylene production in Apple (Malus $x$ domestica Borkh). Postharvest Biology and Technology 87:126-132.

COSTA F, CAPPELLIN L, ZINI E, PATOCCHI A, KELLERHALS M, KOMJANC M, GESSLER C, BIASIOLI F (2013) QTL validation and stability for volatile organic compounds (VOCs) in Apple. Plant Science 211:1-7.

COSTA F, PEACE CP, STELLA S, SERRA S, MUSACCHI S, BAZZANI M, SANSAVINI S, VAN DE WEG WE (2010) QTL dynamics for fruit firmness and softening around an ethylene-dependent polygalacturonase gene in Apple (Malus x domestica Borkh). Journal of Experimental Botany 61:3029-3039.

COSTA F, VAN DE WEG WE, STELLA S, DONDINI L, PRATESI D, MUSACCHI S, SANSAVINI S (2008) Map position and functional allelic diversity of Md-Exp7 a new putative expansin gene associated with fruit softening in apple (Malus $x$ domestica Borkh) and pear (Pyrus communis). Tree Genetics \& Genomes 4:575-586.

DAVEY M, W KENIS K, KEULEMANS J (2006) Genetic Control of Fruit Vitamin C Contents. Plant Physiology 142:343-351.

DEVOGHALAERE F, DOUCEN T, GUITTON B, KEELING J, PAYNE W, LING TJ, ROSS JJ, HALLETT IT, GUNASEELAN K, DAYATILAKE GA, DIAK R, BREEN KC, TUSTIN DS, COSTES E, CHAGNÉ D, SCHAFFER RJ, DAVID KM (2012) A genomics approach to understanding the role of auxin in apple (Malus $x$ domestica) fruit size control. BMC Plant Biology 12,7.

DI GUARDO M, TADIELLO A, FARNETI A, LORENZ G, MASUERO D, VRHOVSEK U, COSTA G, VELASCO R, COSTA F (2013) A Multidisciplinary Approach Providing New Insight into Fruit Flesh Browning Physiology in Apple (Malus $x$ domestica Borkh). PLoS ONE 8(10): e78004.

DIRLEWANGER E, CARDINER G, BOUDEHRI K, RENAUD C, MONLLOR S, ILLA E, HOWAD W, ARÚS P, CROSET C, POËSSEL JL, MAUCOURT M, DEBORDE C, MOIN A (2009) Detection of QTLs controlling major fruit quality components in peach within the european project ISAFRUIT. Acta Hort. (ISHS) 814:533-538.

DIRLEWANGER E, COSSON P, BOUDEHRI K, RENAUD C, CAPDEVILLE G, TAUZIN Y, LAIGRET F, MOING A (2006) Development of a secondgeneration genetic linkage map for peach [Prunus persica $(\mathrm{L})$ Batsch] and characterization of morphological traits affecting flower and fruit. Tree Genetics and Genomes 3:1-13.

DIRLEWANGER E, GRAZIANO E, JOOBEUR T, GARRIGE-CALDERÉ F, COSSON P, HOWAD W, ARÚS P (2004) Comparative mapping and marker-assisted selection in Rosaceae fruit crops. Proceedings of the National Academy of Sciences USA 101:9891-9896.

DIRLEWANGER E, COSSON P, TAVAUD M, ARANZANA J, POIZAT C, ZANETTO A, ARÚS P, LAIGRET F (2002) Development of microsatellite markers in peach [Prunus persica (L)Batsch] and their use in genetic diversity analysis in peach and sweet cherry (Prunus avium L). Theoretical Applied Genetics 105:127-138.

DIRLEWANGER E MOING A ROTHAN C SVANELLA L PRONIER V GUYE A PLOMION C AND MONET C (1999) Mapping QTLs controlling fruit quality in peach Theoretical Applied Genetics 98:18-31.

DIRLEWANGER E, PRONIER V, PARVERY C, ROTHAN C, GUYE A, MONET R (1998) Genetic linkage map of peach [Prunus persica (L) 
Batsch] using morphological and molecular markers. Theoretical Applied Genetics 97:888-895.

DIRLEWANGER E, PASCAL T, ZUGER C, KERVELLA J (1996) Analysis of molecular markers associated with powdery mildew resistance genes in peach [Prunus persica (L) Batsch] x Prunus davidiana hybrids. Theor Appl Genet 93:909-919.

DUNEMANN F, ULRICH D, BOUDICHEVSKAIA A, GRAFE C, WEBER WE (2009) QTL mapping of aroma compounds analysed by headspace solid-phase microextraction gas chromatography in the apple progeny 'Discovery' x 'Prima'. Mol Breeding 23:501-521.

DUNEMANN F, ULRICH D, MALYSHEVA-OTTO L, WEBER WE, LONGHI S, VELASCO R, COSTA F (2012) Functional allelic diversity of the apple alcohol acyl-transferase gene MdAAT1 associated with fruit ester volatile contents in apple cultivars. Mol Breeding 29:609-625.

EDUARDO I, PACHECO I, CHIETERA G, BASSI S, POZZI C, VECCHIETTI A, ROSSINI L (2011) QTL analysis of fruit quality traits in two peach intraspecific population and importance of maturity date pleiotropic effect. Tree Genetics and Genomes 7:323-335.

EDUARDO I; CHIETERA G; PIRONA R; PACHECO I; TROGGIO M; BANCHI E; BASSI D; ROSSINI L; VECCHIETTI A; POZZI C (2013) Genetic dissection of aroma volatile compounds from the essential oil of peach fruit: QTL analysis and identification of candidate genes using dense SNP maps. Tree Genetics \& Genomes 9:189-204.

ETIENNE C, ROTHAN C, MOING A, PLOMOION C, BODENES C, SVANELLA-DUMAS L, COSSON P, PRONIER V, MONET R, DIRLEWNAGER E (2002) Candidate genes and QTLs for sugar and organic acid content in peach (Prunus persica (L) Batsch). Theoretical Applied Genetics 105:145-159.

FAOSTAT (2013) FAO Stadistical Yearbook 2011. http: / / faostatfaoorg/ site/567/ DesktopDefaultaspx?PageID=567\# ancor

ILLA E, SARGENT D, GIRONA E, BUSHAKRA J, CESTARO A, CROWHURST R, PINDO M, CABRERA A, VAN DER KNAAP E, IEZZONI A, et al. (2011) Comparative analysis of rosaceous genomes and the reconstruction of a putative ancestral genome for the family. BMC Evolutionary Biology 11:9.

ILLA E, EDUARDO I, AUDERGON J, BARALE F, DIRLEWANGER E, LI X, MOING A, LAMBERT P, LE DANTEC L, GAO Z, et al. (2010) Saturating the Prunus (stone fruits) genome with candidate genes for fruit quality. Molecular Breeding 1:16

INOUE E, MATSUKI Y, ANZAI H, EVANS K (2007) Isolation and characterization of microsatellite markers in Japanese pear (Pyrus pyrifolia Nakai). Molecular Ecology Notes 7:445-447.

IWATA H, HAYASHI T, YAMAMOTO T (2013) Potential assessment of genome-wide association study and genomic selection in Japanese pear Pyrus pyrifolia. Breed Sci 63:125-140.

KENIS K, KEULEMANS J, DAVEY MW (2008) Identification and stability of QTLs for fruit quality traits in Apple. Tree Genetics \& Genomes 4:647-661.

KHAN SA, CHIBON PY, DE VOS RCH, SCHIPPER BA, WALRAVEN E, BEEKWILDER J, VAN DIJK T, FINKERS R, VISSER RGF, VAN DE WEG EW, BOVY A, CESTARO A, VELASCO R, JACOBSEN E, SCHOUTEN EJ (2012) Genetic analysis of metabolites in apple fruits indicates an mQTL hotspot for phenolic compounds on linkage group 16. Journal of Experimental Botany 63:2895-2908.

KING GJ, LYNN JR, DOVER CJ, EVANS KM, SEYMOUR GB (2001) Resolution of quantitative trait loci for mechanical measures accounting for genetic variation in fruit texture of apple (Malus pumila Mill). Theor Appl Genet 1227-1235.

KING GJ, MALIEPAARD C, LYNN JR, ALSTON FH, DUREL CE, EVANS KM, GRIFFON B, LAURENS F, MANGANARIS AG, SCHREVENS E, TARTARINI S, VERHAEGH J (2000) Quantitative genetic analysis and comparison of physical and sensory descriptors relating to fruit flesh firmness in apple (Malus pumila Mill). Theor Appl Genet 100:1074-1084.

KLAGGES C, CAMPOY JA, QUERO-GARCÍA J, GUZMÁN A, MANSUR L, GRATACOS E, SILVA H, ROSYARA UR, IEZZONI A, MEISEL L, DIRLEWANGER E (2013) Construction and Comparative Analyses of Highly Dense Linkage Maps of Two Sweet Cherry Intra-Specific Progenies of Commercial Cultivars. PLoS ONE 8(1):e54743.

KRAAKMAN ATW, MARTÍNEZ F, MUSSIRALIEV B, V EEUWIJK FA, NIKS RE (2006) Linkage disequilibrium mapping of morphological resistance and other agronomically relevant traits in modern spring barley cultivars. Mol Breed 17:41-58.

KOEPKE T, SCHAEFFER S, KRISHNAN V, JIWAN D, HARPER A, WHITING M, ORAGUZIE N, DHINGRA A (2012) Rapid gene-based SNP and haplotype marker development in non-model eukaryotes using 3'UTR sequencing. BMC Genomics 13:18.
KUMAR S, GARRICK DJ, BINK M, WHITWORTH C, CHAGNÉ D, VOLZ R (2013) Novel genomic approaches unravel genetic architecture of complex traits in apple. BMC Genomics 14:393.

LAMBERT P, DICENTA F, RUBIO M, AUDERGON J (2007) QTL analysis of resistance to sharka disease in the apricot (Prunus armeniaca L) 'Polonais' $x$ 'Stark Early Orange' F1 progeny. Tree Genetics and Genomes 3:299-309.

LONGHI S, HAMBLIN M, T, TRAINOTTI L, PEACE C, P, VELASCO R, COSTA F (2013) A candidate gene based approach validates Md-PG1 as the main responsible for a QTL impacting fruit texture in apple (Malus $x$ domestica Borkh). BMC Plant Biology 13,37.

LONGHI S, MORETTO M, VIOLA R, VELASCO R, COSTA F (2012) Comprehensive QTL mapping survey dissects the complex fruit texture physiology in apple (Malus $x$ domestica Borkh). Journal of Experimental Botany 63:1107-1121.

MELLIDOU I, CHAGNÉ D, LAING WA, KEULEMANS J, DAVEY MW (2012) Allelic Variation in Paralogs of GDP-L-GalactosePhosphorylase Is a Major Determinant of Vitamin C Concentrations in Apple Fruit. Plant Physiology 160:1613-1629.

MICHELETTI D, TROGGIO M, ZHARKIKH A, COSTA F, MALNOY M, VELASCO R, SALVI S (2011) Genetic diversity of the genus Malus and implications for linkage mapping with SNPs. Tree Genetics and Genomes 7:857-868.

MORIMOTO T, HIRAMATSU Y, BANNO K (2013) A Major QTL Controlling Earliness of Fruit Maturity Linked to the Red leaf/Red flesh Trait in Apple cv 'Maypole'. J Japan Soc Hort Sci 82:97-105.

MONTANARI S, SAEED M, KNÄBEL M, KIM YK, TROGGIO M, MALNOY M, VELASCO R, FONTANA P, WON KH, DUREL C- PERCHEPIED L, SCHAFFER R, WIEDOW C, BUS V, BREWER L, GARDINER SE, CROWHURST RN, CHAGNÉ D (2013) Identification of Pyrus Single Nucleotide Polymorphisms (SNPs) and Evaluation for Genetic Mapping in European Pear and Interspecific Pyrus Hybrids. PLoS ONE 8:(10), e 77022.

OGUNDIWIN E, PEACE C, NICOLET C, RASHBROOK V, GRADZIEL T, BLISS F, PARFITT D, CRISOSTO C (2008) Leucoanthocyanidin dioxygenase gene (PpLDOX): a potential functional marker for cold storage browning in peach. Tree Genetics and Genomes 4:543-554.

PATERSON AH (1996) Making genetic maps In: Paterson AH (ed) Genome Mapping in Plants R G Landes Company San Diego California. Academic Press Austin Texas 23-39.

POTTS S, M, KHAN M, A, HAN Y, KUSHAD M, M, KORBAN S, S (2013) Identification of Quantitative Trait Loci (QTLs) for Fruit Quality Traits in Apple. Plant Mol Biol Rep DOI 10.1007/s11105-013-0634-8.

QUILOT B, WU BH, KERVELLA J, GENARD M, FOULONGNE M, MOREAU K (2004) QTL analysis of quality traits in an advanced backcross between Prunus persica cultivars and the wild relative species P davidiana. Theoretical Applied Genetics 109:884-897.

SALVI S (2007) Conserved non-coding genomic sequences associated with a fl owering-time quantitative trait locus in maize. Proc Natl Acad Sci 104:11376-11381.

SHULAEV V, SARGENT DJ, CROWHURST RN, MOCKLER TC, FOLKERTS O, DELCHER AL, JAISWAL P, MOCKAITIS K, LISTON A, MANE SP, et al. (2011) The genome of woodland strawberry (Fragaria vesca). Nature genetics 43:109-116.

STOECKLI S, MODY K, GESSLER C, CHRISTEN D, DORN S (2009) Quantitative trait locus mapping of resistance in apple to Cydia pomonella and Lyonetia clerkella and of two selected fruit traits. Ann Appl Biol 154:377-387.

STOECKLI S, MODY K, GESSLER C, PATOCCHI A, JERMINI M, DORN S (2008) QTL analysis for aphid resistance and growth traits in Apple. Tree Genetics and Genomes 4:833-847.

SUN L, ZHANG Q, XU Z, YANG W, GUO Y, LU J, PAN H, CHENG T, CAI $M$ (2013) Genome-wide DNA polymorphisms in two cultivars of mei (Prunus mume sieb et zucc). BMC Genetics 14:98.

TANKSLEY SD (1993) Mapping polygenes. Annu Rev Genet 27:205-233.

TRACY WF, WHITT SR, BUCKLER ES (2006) Recurrent mutation and genome evolution: Example of Sugary1 and the origin of sweet maize. Crop Sci 46:S49-S54.

VELASCO R, ZHARKIKH A, AFFOURTIT J, DHINGRA A, CESTARO A KALYANARAMAN A, FONTANA P, BHATNAGAR SK, TROGGIO M, PRUSS D (2010) The genome of the domesticated apple (Malus $\times$ domestica Borkh). Nature genetics 42:833-839.

VERDE I, ABBOT A, SCALABRN S, JUNG S, SHU S, MARRONI F, ZHEBENTYAYEVA T, DETTORI M, GRIMWOOD J, CATTONARO F, et al. (2013) The high-quality draft genome of peach (Prunus persica) 
identifies unique patterns of genetic diversity domestication and genome evolution. Nature Genetics 45: 487-494.

VERDE I, BASSIL N, SCALABRIN S, GILMORE B, LAWLEY C, GASIC K, MICHELETTI D, ROSYARA U, CATTONARO F. VENDRAMIN E, et al. (2012) Development and evaluation of a 9K SNP array for peach by internationally coordinated SNP detection and validation in breeding germoplasm. PLoS ONE 7:e35668.

VERDE I, QUARTA R, CEDROLA C, DETTORI MT (2002) QTL analysis of agronomic traits in a BC1 peach population. Acta Horticlturae 592:291-297.

VOGT J, SCHILLER D, ULRICH D, SCHWAB W, DUNEMANN F (2013) Identification of lipoxygenase (LOX) genes putatively involved in fruit flavour formation in apple (Malus $x$ domestica). Tree Genetics and Genomes DOI 101007/s11295-013-0653-5.

WANG L, ZHAO S, GU C, ZHOU Y, ZHOU H, MA J, CHENG J, HAN Y (2013) Deep RNA-Seq uncovers the peach transcriptome landscape. Plant Molecular Biology 83:365-377.

WU J, WANG Z, SHI Z, ZHANG S, MING R, ZHU S, KHAN MA, TAO S, KORBAN SS, WANG H, et al. (2013) The genome of the pear (Pyrus bretschneideri Rehd). Genome research 23:396-408.

WU SB, WIRTHENSOHN M, HUNT P, GIBSON J, SEDGLEY M (2008) High resolution melting analysis of almond SNPs derived from ESTs. Theoretical and Applied Genetics 118:1-14.

XU K, WANG A, BROWN S (2012) Genetic characterization of the Ma locus with $\mathrm{pH}$ and titratable acidity in Apple. Molecular Breeding 30: 899-912.
YOUNG ND (1996) QTL mapping and quantitative disease resistance in plants. Annual Review Phytopathol 34:479-501.

ZHANG G, SEBOLT A M, SOORIYAPATHIRANA S S, WANG D, BINK M, OLMSTEAD JW, LEZZONI AF (2010) Fruit size QTL analysis of an F1 population derived from a cross between a domesticated sweet cherry cultivar and a wild forest sweet cherry. Tree Genetics \& Genomes 6:25-36.

ZHANG Q, CHEN W, SUN L, ZHAO F, HUANG B, WANG J, YANG W, TAO Y, YUAN Z, FAN G, XING Z, HAN C, PAN H, ZHONG X, SHI W, LIANG X, DU D, SUN F, XU Z, HAO R, LV T, LV Y, ZHENG Z, SUN M, LUO L, CAI M, GAO Y, WANG J, YIN Y, XU X, CHENG T, WANG J (2012a) The genome of Prunus mume. Nature Communications, 3.

ZHANG Q, MA B, LI H, CHANG Y, HAN Y, LI J, WEI G, ZHAO S, KHAN M A, ZHOU Y, GU C, ZHANG X, HAN Z, KORBAN SS, LI S, HAN Y (2012b) Identification characterization and utilization of genome-wide simple sequence repeats to identify a QTL for acidity in Apple. BMC Genomics 13, 537.

ZHU C, GORE M, BUCKLER E, YU J (2008) Status and Prospects of Association Mapping in Plants. The Plant Genome 1:5-20.

ZINI E, BIASIOLI F, GASPERI F, MOTT D, APREA E, MARK TD, PATOCCHI A, GESSLER C, KOMJANC M (2005) QTL mapping of volatile compounds in ripe apples detected by proton transfer reactionmass spectrometry. Euphytica 145:269-279. 